\title{
Role Identities of Japanese Teachers of English at Japanese
}

\section{Universities}

\section{Hiroshi Moritani}

Hiroshima University of Economics

\section{Chiaki Iwai \\ Hiroshima City University}

\section{Reference Data:}

Moritani, H., \& Iwai, C. (2019). Role identities of Japanese teachers of English at Japanese universities. In P. Clements, A. Krause, \& P. Bennett (Eds.), Diversity and inclusion. Tokyo: JALT.

As part of a larger study of university English teachers, this paper presents a hypothetical model of the critical influences on the construction of role identities (i.e., how teachers understand their teaching roles) using data generated from in-depth interviews with 12 Japanese teachers of English at Japanese universities. To inductively create a hypothetical model based on the actual voices of these participants, the analysis utilizes a modified grounded theory approach (Kinoshita, 2003). We report that five critical influences emerged: (a) classroom experiences as a learner, (b) professional development, (c) contextual factors, (d) classroom experiences as a teacher, and (e) teacher-internal factors. We present the findings with reference to previous studies in language teacher cognition research.

本稿では、大学英語教師に関する研究の一部として、日本の大学で教える12人の日本人英語教師との深層インタビューか ら得たデータをもとに、彼らの役割アイデンティティ(教師の役割の理解)の構築に関与する重要な影響要因を示す仮説モデ ルを提示する。研究協力者の実際の言葉をもとに帰納的に仮説王デルを構築するために、分析に修正版グラウンデッド・セ才 リー・アプローチ(木下，2003）を用いた。本稿では、役割アイデンティティの構筑に関与する5つの重要な影響要因( 学䏨者

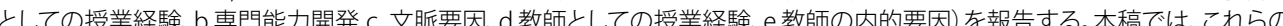
要因を言語教師認知研究の先行研究に照らしながら提示する。 lassroom practices are partly manifestations of "what teachers know, believe, and think" (Borg, 2003, p. 81). Therefore, the importance of the cognitions of language teachers has been recognized for the last two decades. Although many studies have been conducted on the internal dimensions of language teachers in the Japanese context, few studies have investigated the cognitions of university English teachers (e.g., Nagatomo, 2012). In order to gain additional insight into these teachers' cognitions, the authors carried out an exploratory study with a focus on role identities of university English teachers (i.e., how teachers understand their teaching roles). The overall aim is to identify critical influences on the construction of role identities for both Japanese and non-Japanese teachers of English at Japanese universities and understand how these influences function; this information will help determine which influences should be investigated in future studies. Focusing on Japanese teachers of English, we report on the early stages of this research and propose a hypothetical model that illustrates the influential factors, which are inductively categorized themes identified from interviews with the teachers regarding the construction of role identities.

\section{Theoretical Background}

Language teacher cognition research investigates language teachers' thoughts, knowledge, and beliefs with regard to teaching practices (Borg, 2003). Borg presented a comprehensive framework of dimensions of language teacher cognitions and four factors that influence those cognitions: (a) schooling, (b) professional education, (c) classroom practice, and (d) contextual factors. Borg's framework highlights the complex construction of language teachers' cognitions.

The current study utilized role identity (Farrell, 2011), a relatively new concept in language teacher cognition research (Borg, 2012) defined as "the configuration of interpretations that language teachers attach to themselves, as related to the different roles they enact and the different professional activities that they participate in as well as 
how others see these roles and activities" (Farrell, 2011, p. 55). Farrell suggested that how teachers interpret their roles is "central to the beliefs, assumptions, values, and practices that guide teachers both inside and outside the classroom” (p. 54). Despite its centrality, however, no attempts to explore this concept in Japanese universities appear in the literature.

Role identities can be context sensitive (Farrell, 2011). Farrell specified 16 role identities (e.g., presenter and care provider) that emerged in interviews with three Canadian teachers of ESL. If the participants are a different group of teachers teaching in a different context, however, their role identities could be different because identities are constructed through specific communities of practice (Wenger, 1998). Furthermore, if there are differences in role identities between teachers in different contexts, factors that cause such differences should also be investigated to understand the complex construction of language teacher cognitions.

\section{Methodology \\ Purpose of the Study}

In this study, we explored role identities of Japanese teachers of English teaching at Japanese universities and the factors that relate to the construction of their role identities. Although "role identity" can also include how others see teachers' roles, as defined above, the current study only focused on how teachers themselves view and interpret their own roles.

As mentioned earlier, the cognitions of university English teachers are underresearched and role identities of university English teachers in Japan have not been explored. We adopted a data-driven inductive approach to develop a hypothetical model of construction of role identities based on qualitative data, rather than testing predetermined hypotheses.

\section{The Participants}

The participants were 12 Japanese university teachers of English (four men and eight women), all with more than 10 years of teaching experience at Japanese universities, ranging from 11 to 28 years. Nine were full-time teachers and three were part-time. Four of the full-time teachers worked at national universities, one worked at a public university, and the other four worked at private universities. All teachers taught compulsory English courses within the general education curriculum for 1st- and 2nd- year university students. One teacher led a seminar course on English literature and another taught English teacher education courses in addition to the compulsory English language courses. These two teachers were requested to consider only their compulsory English courses for this study.

As for academic background, five teachers had completed TESOL programs overseas. One specialized in domestic English teacher education. There were four teachers with backgrounds in English literature, all of whom had English teaching certifications for secondary schools. One teacher with a linguistics background and another teacher whose academic background was not in an English-related field did not have language teaching certificates. A summary of the participants' backgrounds, including the pseudonyms used throughout this paper, appears in the Appendix.

\section{Materials and Data Collection}

Data were collected from individual in-depth interviews using three kinds of materials: a list of teacher roles, a mind map sheet, and a time-series sheet. The primary purpose of these materials was to facilitate participants' reflections on their role perceptions because these perceptions are often tacit (Farrell, 2011). The list of teacher roles contained 18 examples of typical teaching roles. Participants were instructed to choose roles relevant to their own teaching and rank those roles based on perceived importance. Next, the mind map sheet was used to depict the conceptual relationship between the roles participants perceived themselves playing. Finally, participants looked back on their past teaching practices and completed the time-series sheet to describe changes in importance of perceived roles (see Moritani, 2018, for a full discussion of the use of these materials). Although these materials were prepared to facilitate the participants' reflections on their perceptions of current and past roles, the completed sheets listing their teachers' roles were also analyzed to illuminate how the participants subjectively perceived their roles.

The interviews were guided by the research materials that each participant had completed. After drawing a mind map, participants were asked to explain why they thought certain roles were important as well as when and how they became aware of that importance. With the completed time-series sheets, participants also detailed what caused any changes in their perceptions during their careers. Follow-up questions were asked to gain further insight. Interviews were conducted in Japanese, audio recorded, and transcribed for analysis. 


\section{Analysis}

Twelve completed sheets listing teachers' roles and transcribed interview data were analyzed. The roles that participants had ranked number one (i.e., most important) were counted. Although the analysis was performed numerically, generalization of the results is not intended.

The transcribed data were analyzed using a modified grounded theory approach (M-GTA; Kinoshita, 2003). M-GTA is a method that allows themes and theories to emerge inductively from qualitative data. A key feature of this method is the writing of systematic notes (worksheets) for each theme (concept) while coding the raw data. Worksheets are designed to record actual data and notes, and the emergent concepts are examined across the whole data set. This coding process continued until no further concepts were created. The notes recorded on the worksheets were useful for categorizing concepts into two levels-a main category and a subcategory - and for formulating theoretical relationships between main categories that constructed the participants' role perceptions. With the application of M-GTA, all the concepts and the hypothetical model were inductively generated without imposing any theoretical framework or preconceived hypothesis.

To ensure the credibility of the analysis, all the concepts initially created by the first researcher were reviewed by the second researcher. Discussions took place when disagreements on interpretation occurred. The hypothetical model was also reviewed several times and finalized by both researchers. The data set was written in Japanese, and the analysis was conducted in Japanese. The results were translated into English for inclusion here.

\section{Findings}

Role Identities

Table 1 shows a summary of the most important teacher roles selected by participants (see Appendix for individual responses). Facilitator and motivator were the roles most often selected, with five participants choosing each role.
Table 1. Summary of Most Important Teacher Roles ( $=12)$

\begin{tabular}{lcc}
\hline Most important roles & Number & Percentage \\
\hline Facilitator & 5 & $41.6 \%$ \\
Motivator & 5 & $41.6 \%$ \\
English expert & 2 & $16.7 \%$ \\
Representative of a culture & 2 & $16.7 \%$ \\
Language model & 2 & $16.7 \%$ \\
Lecturer & 1 & $8.3 \%$ \\
Entertainer & 1 & $8.3 \%$ \\
Japanese & 1 & $8.3 \%$ \\
\hline
\end{tabular}

Note. Percentage is of the total number of participants. Participants were allowed to choose more than one role as number one, so numbers add up to more than the number of participants (and percentages total more than 100).

Although facilitator and motivator were the roles most recognized by the participants, there were other roles that some perceived as the most important. English expert, representative of a culture, and language model were ranked most important by two participants each. Additionally, two of the participants with literature backgrounds perceived themselves as a representative of a culture transmitting knowledge of a foreign culture that they had gained during their studies of English literature. Lecturer, entertainer, and Japanese were ranked as most important by one teacher each. These results reflect the variety of teachers who participated in this study.

\section{Influential Factors}

As a result of the M-GTA analysis, we formulated a hypothetical model explaining the influences that were related to the participants' role identities (Figure 1). The model was formulated with five main categories of such influences, consisting of eight subcategories and 25 concepts. As indicated, the five categories of influences on role identities were (a) classroom experiences as a learner, (b) professional development, (c) contextual factors, (d) classroom experiences as a teacher, and (e) teacher-internal factors. In the following section, these five categories are illustrated with participants' remarks. The illustration of each case is somewhat generic because our purpose is to propose a hypothetical model 
rather than give in-depth descriptions. In addition, explanations for some of the concepts (themes) are omitted due to limited space.

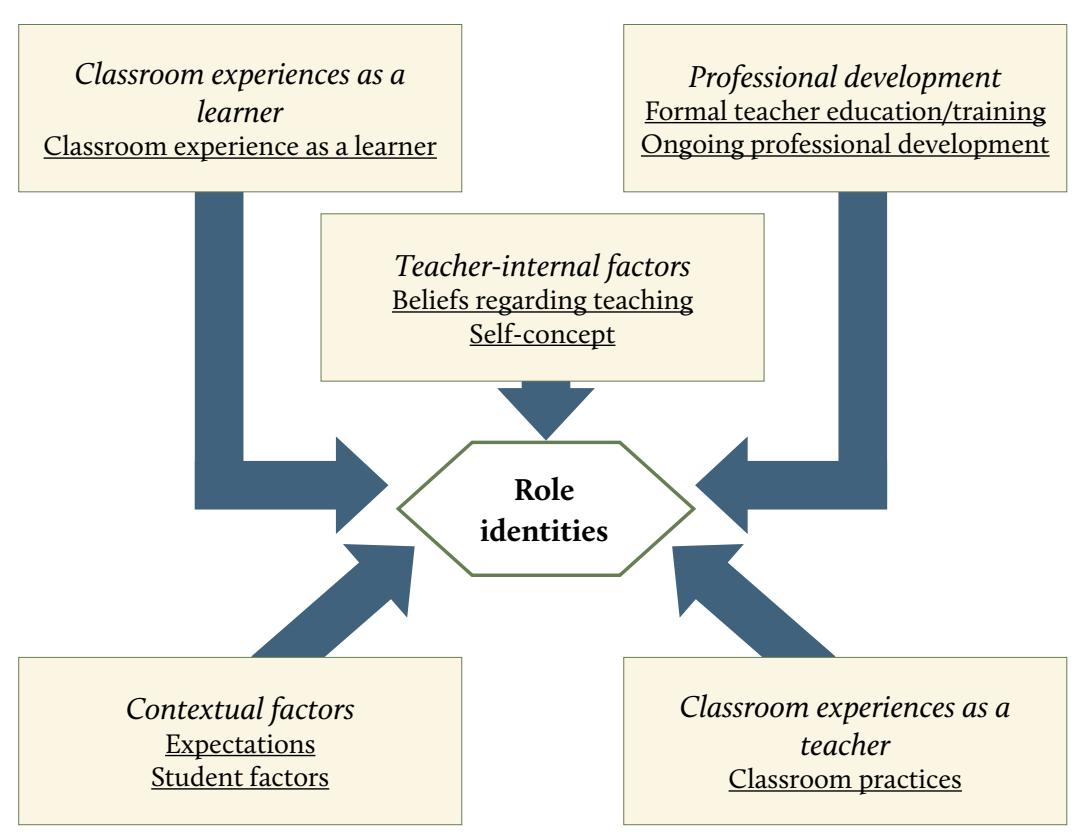

Figure 1. Factors that construct the participants' role identities. Italics indicate main categories, underlining indicates subcategories, and arrows indicate influential relationships.

\section{Classroom Experiences as a Learner}

Classroom experiences as a learner was one of the themes expressed by the participants. The participants' remarks regarding their past (language) learning experiences were synthesized into the subcategory "classroom experiences as a learner." Because there were no related subcategories, the main category with only one subcategory with the same name was established.

Nine participants pointed out either positive or negative influences of their own classroom experiences as a learner on their teaching practices. Known as "apprenticeship of observation" (Lortie, 1975), teachers' past classroom experiences have been recognized as a powerful factor in teachers' practices and cognitions (e.g., Johnson, 1994). In the present study, Nami, who perceived herself as an English expert, talked about the influences of her former English teachers on her classroom practices: "I remember all the English teachers I had before. They gave me strong impressions. This is important to my teaching practices, which is based on the experiences I had." She remembered her own classroom experience as a learner as positive and had retained it as a model for her teaching.

By contrast, there were three teachers who mentioned the influence of their own classroom experiences as learners that functioned as a negative example. Takako, whose prime role identity was facilitator, noted: "I really liked my former teachers, but, sorry to say, they are examples of how not to behave." It can thus be assumed that her former teachers used a traditional rather than facilitative teaching style. This indicates that even negative classroom experiences can shape participants' teaching practices.

\section{Professional Development}

Eight participants pointed out the influence of professional development when they talked about their roles. This category consists of two subcategories: (a) formal teacher education and training and (b) ongoing professional development.

The first subcategory is related to the professional development programs the participants took part in when they started their teaching careers (e.g., teacher education courses in undergraduate and graduate programs). It also covers teacher training programs provided by formal organizations (e.g., TESOL certification) and those provided by private English language schools.

There were two opposing views on teacher education programs. Four participants stated that such programs positively influence their practices. For example, Chika, whose primary role identities were facilitator and English expert, described the significant influence of teacher education programs on her teaching: "I learned at a TESOL program. Things I learned there have influenced me a great deal regarding my teaching at a university." She further explained that she learned an inductive approach to language teaching at a TESOL program, which was different from the way she had learned English in Japan. The teacher education program in which she participated thus greatly influenced her role identity as a facilitator.

On the other hand, four participants denied the influence of a teacher education program on their teaching practices. For example, Hayato, who perceived himself as an entertainer, a representative of a culture, and a language model, noted that he did not value what he had learned during his teacher education program: "Things that I had learned in a teacher training program were not useful when I started teaching. Or 
perhaps I should say I didn't remember a thing." This example is aligned with previous studies that have reported that the impact of teacher training programs on teacher cognition was not strong enough to transform that cognition (Peacock, 2001).

The second subcategory of professional development includes activities like class observation, self-study, and involvement with teacher organizations. Ten participants commented on their efforts to improve their teaching through these methods. Ikumi, who perceived herself as a facilitator, recounted that she had been to workshops on writing instruction and active learning, and she evaluated one of them with this comment: "A workshop on active learning was really interesting. That's exactly what I do. Facilitating. I learned a lot from it." She regarded herself as a facilitator-a perception reinforced by attending professional development programs.

\section{Contextual Factors}

The third major influence was contextual factors. These factors include two subcategories: expectations and student factors.

Three participants commented on the expectations of the university-specifically unified curriculums. Asako, whose primary role identity was facilitator, reported that her teaching practices and roles were affected by this university policy. She said that the system was easy for teachers if all the teachers used the same textbook and gave the same prepared test but stated, "What I learned in the TESOL program was a learner-centered approach, and this is the opposite, because the university decides everything." She expressed helplessness about her teaching context because, as a part-time teacher, she was expected to teach what she was assigned.

Another theme that nine participants expressed regarding their teaching context concerned their students. There were three areas of student factors: maturity, motivation, and English ability. Two participants discussed student maturity, three student motivation to learn English, and four students' English ability. For example, Chika disclosed a candid impression of her students: "They are not mature, really not mature. I have to spoon-feed them." She described her situation as having to act as a care provider, like the students' parents. As this example shows, the participants adjusted their roles as teachers to their students.

Classroom Experiences as a Teacher

Teachers learn from experience and refine their teaching styles accordingly. Six participants in this study talked about past trial and error and stated that their current teaching practices were based upon such experiences. Saori, who perceived herself as a motivator, explained that classroom experience was the most influential factor for her role identity, saying, "There are many things that I do based on my experience. I gained my teaching style from my experience." Her remarks indicated that she had learned what worked for her students and what did not from her own past experiences of success and failure.

Kyosuke, whose role identities were facilitator, motivator, and language model, also pointed out the necessity of experience in forming teaching styles. He used to see himself as an English expert, but he recognized the importance of facilitation after attending several workshops and seminars on active learning. He also noted: "You can't facilitate students if you don't have experience." This implies that teachers cannot adopt other teacher roles without experiences even if professional development brings new ideas and knowledge about language teaching. Kyosuke's case demonstrates that actual teaching practice and experience are among the most important factors in teacher development, as Tsui (2003) emphasized.

\section{Teacher-Internal Factors}

Teacher-internal factors often emerged when the participants talked about their role identities. There are two subcategories: beliefs regarding teaching and self-concepts.

In relation to their role identities, four participants mentioned beliefs regarding grammar instructions. Masako commented, "As for grammar, we have to teach it." Grammar instruction has always been one of the important issues in foreign language teaching (e.g., Ellis, 2006), and teachers' views on grammar instruction have been investigated in previous teacher cognition studies (e.g., Phipps \& Borg, 2009). In this study, teachers like Masako stated that teaching grammar was one aspect of their job, and these beliefs seemed to be related to certain role perceptions (e.g., lecturer and English expert).

How teachers see themselves can also be an influential factor. These references were labeled as self-concept. Hayato stated that his researcher-self influenced his role identity as an English teacher, saying, "This is kind of a literature researcher way of thinking. I teach classes for students to become able to accept a wide range of values through learning English." Hayato's view is evidenced by his choice of "representative of a culture" as one of his chosen role identities. Nagatomo (2012) portrayed one Japanese teacher with a literature background who believed herself to be teaching more than just language, and Hayato's case is consistent with that view. 


\section{Discussion}

As presented in Table 1, there were various views among the participants on their role identities, although this paper has only explored those ranked as number one (i.e., most important or core) role identities for the participants. Farrell (2011) identified 16 role identities and delineated the frequently emerging role identities in his data, but it was unclear whether these frequently emerging roles could be determined as core or peripheral role identities for his participants. The current study, however, suggested that there are core and peripheral differences in the role identities of the participants, which became evident when they were asked to rank the roles. This demonstrates the complex construction of role identities, which are unique to each teacher, as several different roles were marked as the most important by each, and some roles were recognized by participants as more central roles than others.

In this paper we have also presented a hypothetical model that illustrates the five main categories of critical influences for unique role identities of individual teachers (Figure 1). Four of the five categories (i.e., excluding teacher-internal factors) are congruent with those indicated in Borg (2003). Although there are differences in the labels due to the inductive approach to analysis of this study, the categories are virtually the same. The framework in Borg (2003) was a synthesis of 64 scholarly articles on language teachers' cognitions, as such it is an adequate basis for the hypothesis presented in this paper. We believe that the hypothetical model with these four factors that this study has reached and the method of analysis were both valid.

Serious consideration is needed, however, for the last main category, teacher-internal factors, as to whether it should be included in future studies to examine to what extent the factors emerged in this study function to construct role identities. This category does not appear in Borg's (2003) framework because teacher-internal factors are a part of language teacher cognition. We surmise that teacher-internal factors work as a mediator between the four main categories; thus, construction of role identities is a product of teacher-internal factors. As Farrell (2011) argued, role identities are "central to the beliefs, assumptions, values, and practices that guide teachers both inside and outside the classroom" (p. 54). Therefore, considering teacher internal factors in this study as a construct completely distinguished from role identities may be inadequate.

Further directions of this study will be twofold. First, each case should be examined in detail, and follow-up interviews should be conducted if necessary. Because the overall aim of this study was to develop a hypothetical model inductively from the data, the descriptions of cases presented were somewhat generic. It is not clear why some factors in this study had significant impacts on some participants but not on others. For example, teacher education programs facilitated teacher development for some participants (e.g., Chika), but they did not for others (e.g., Hayato). Causes of these differences should be investigated in future studies. Another future direction is to examine how strongly each of the critical influences identified contributes to the construction of role identities. Language teacher cognition studies tend to favor qualitative approaches. Although they have provided great insights into teacher cognitions, contradictory results have been reported because the context of each study varies greatly from others (Basturkmen, 2012). As Basturkmen (2012) called for a "research agenda beyond case studies" (p. 282), a quantitative method aiming to generalize language teacher cognitions will be a valuable direction for study. Regarding the current study, based on the hypothetical model built for critical influences on role identities, we are planning to develop a questionnaire and conduct a survey with a wider population to determine the intensity that various critical influences have on role identities. The results will benefit teacher educators and researchers in related fields.

\section{Conclusion}

Using a qualitative research approach, this study explored role identities of 12 Japanese teachers of English at Japanese universities. The results presented participants' unique interpretations of their roles as English teachers, and the critical influences for them were proposed in the form of a hypothesis. As previous research has shown in language teacher cognition, these influences have a significant impact on teachers' understanding of their roles. It is, therefore, important to take teachers' previous experiences into consideration to fully understand their development as professionals.

\section{Acknowledgments}

This work was supported by JSPS KAKENHI Grant Number JP17K02894. The authors would like to thank the 12 teachers who took part in this study.

\section{Bio Data}

Hiroshi Moritani is an English lecturer at Hiroshima University of Economics. His research interests are $\mathrm{L} 2$ motivation and teacher cognition. He is currently working toward his PhD degree at Hiroshima City University.

Chiaki Iwai, PhD, a professor at Hiroshima City University, has been a JALT member over 30 years. His main research interests include EFL learners' use of communication strategies and their interlanguage pragmatic abilities. 


\section{References}

Basturkmen, H. (2012). Review of research into the correspondence between language teachers' stated beliefs and practices. System, 40(2), 282-295. https://doi.org/10.1016/j.system. 2012.05.001

Borg, S. (2003). Teacher cognition in language teaching: A review of research on what language teachers think, know, believe, and do. Language Teaching, 36(2), 81-109. https://doi.org/10.1017/ S0261444803001903

Borg, S. (2012). Current approaches to language teacher cognition research: A methodological analysis. In R. Barnard, \& A. Burns (Eds.), Researching language teacher cognition and practice: International case studies (pp. 11-29). Bristol, England: Multilingual Matters. https://doi. org/10.1017/S0261444803001903

Ellis, R. (2006). Current issues in the teaching of grammar: An SLA perspective. TESOL Quarterly, 40(1), 83-107. https://doi.org/10.2307/40264512

Farrell, T. S. C. (2011). Exploring the professional role identities of experienced ESL teachers through reflective practice. System, 39(1), 54-62. https://doi.org/10.1016/j.system.2011.01.012

Johnson, K. E. (1994). The emerging beliefs and instructional practices of preservice English as a second language teachers. Teaching and Teacher Education, 10(4), 439-452. https://doi. org/10.1016/0742-051X(94)90024-8

Kinoshita,Y. 木下康仁 (2003).グラウンデッド・セオリー・アプローチの実践—質的研究への誘い [Practice of the grounded theory approach: Invitation to qualitative research]. Tokyo: 弘文堂 [Kobundo].

Lortie, D. C. (1975). Schoolteacher: A sociological study. Chicago, IL: University of Chicago Press.

Moritani, H. (2018). Reflecting on teacher roles using visual methods. In P. Clements, A. Krause, \& P. Bennett (Eds.), Language teaching in a global age: Shaping the classroom, shaping the world (pp.1-7). Tokyo: JALT. Retrieved from http://jalt-publications.org/sites/default/files/pdf-article/ jalt2017-pcp-001.pdf

Nagatomo, D. H. (2012). Exploring Japanese university English teachers' professional identity. Bristol, England: Multilingual Matters.

Peacock, M. (2001). Pre-service ESL teachers' beliefs about second language learning: A longitudinal study. System, 29(2), 177-195. https://doi.org/10.1016/S0346-251X(01)00010-0

Phipps, S., \& Borg, S. (2009). Exploring tensions between teachers' grammar teaching beliefs and practices. System, 37(3), 380-390. https://doi.org/10.1016/j.system.2009.03.002

Tsui, A. (2003). Understanding expertise in teaching: Case studies of second language teachers. Cambridge, England: Cambridge University Press.

Wenger, E. (1998). Communities of practice. Cambridge, England: Cambridge University Press.

\section{Appendix}

Summary Details of Participants

\begin{tabular}{|c|c|c|c|c|c|c|}
\hline Name & Gender & $\begin{array}{l}\text { Teaching } \\
\text { experience }\end{array}$ & Employment & Workplace & $\begin{array}{l}\text { Academic } \\
\text { background }\end{array}$ & Most important role(s) \\
\hline Asako & $\mathrm{F}$ & 19 years & Part-time & $\begin{array}{l}\text { Not } \\
\text { singular }\end{array}$ & TESOL & Facilitator \\
\hline Kanako & $\mathrm{F}$ & 13 years & Full-time & Nat'l univ. & TESOL & $\begin{array}{l}\text { Japanese, } \\
\text { Facilitator }\end{array}$ \\
\hline Saori & $\mathrm{F}$ & 26 years & Part-time & $\begin{array}{l}\text { Not } \\
\text { singular }\end{array}$ & TESOL & Motivator \\
\hline Takako & $\mathrm{F}$ & 17 years & Full-time & Nat'l univ. & TESOL & Facilitator \\
\hline Nami & $\mathrm{F}$ & 12 years & Full-time & $\begin{array}{l}\text { Private } \\
\text { univ. }\end{array}$ & Literature & English expert \\
\hline Hayato & $\mathrm{M}$ & $\begin{array}{l}11 \text { years } \\
\text { (He also led } \\
\text { a seminar.) }\end{array}$ & Full-time & Public univ. & Literature & $\begin{array}{l}\text { Entertainer, } \\
\text { Representative of a } \\
\text { culture, } \\
\text { Language model }\end{array}$ \\
\hline Masako & $\mathrm{F}$ & 13 years & Full-time & $\begin{array}{l}\text { Private } \\
\text { univ. }\end{array}$ & Literature & $\begin{array}{l}\text { Motivator, Lecturer, } \\
\text { Representative of a } \\
\text { culture }\end{array}$ \\
\hline Yasushi & M & 28 years & Full-time & Nat'l univ. & Literature & Motivator \\
\hline Ikumi & $\mathrm{F}$ & 13 years & Full-time & Nat'l univ. & $\begin{array}{l}\text { Non-English } \\
\text { related field }\end{array}$ & Facilitator \\
\hline Kyosuke & $\mathrm{M}$ & 14 years & Full-time & $\begin{array}{l}\text { Private } \\
\text { univ. }\end{array}$ & Linguistics & $\begin{array}{l}\text { Facilitator, Motivator, } \\
\text { Language model }\end{array}$ \\
\hline Shigeki & M & $\begin{array}{l}27 \text { years } \\
\text { (He was } \\
\text { involved } \\
\text { in teacher } \\
\text { education } \\
\text { program.) }\end{array}$ & Full-time & $\begin{array}{l}\text { Private } \\
\text { univ. }\end{array}$ & $\begin{array}{l}\text { English } \\
\text { education }\end{array}$ & Motivator \\
\hline Chika & $\mathrm{F}$ & 11 years & Part-time & $\begin{array}{l}\text { Not } \\
\text { singular }\end{array}$ & TESOL & $\begin{array}{l}\text { Facilitator, } \\
\text { English expert }\end{array}$ \\
\hline
\end{tabular}

Note. All names are pseudonyms. Part-time teachers teach at two or more universities. 